\title{
Molecular sexing and population genetic inference using a sex-linked microsatellite marker in the nine-spined stickleback (Pungitius pungitius)
}

Takahito Shikano*, Gábor Herczeg and Juha Merilä

\begin{abstract}
Background: Sex-specific DNA markers can serve as tools for molecular sex identification, as well as for population genetic inferences. We investigated the potential utility of a microsatellite marker located on sex chromosomes for molecular sexing of Fennoscandian nine-spined sticklebacks (Pungitius pungitius). In addition, we assessed the patterns of allelic differentiation between $X$ and $Y$ chromosomes across the populations to examine if the sex chromosomes had been highly differentiated prior to the postglacial recolonization of Fennoscandia.

Findings: A clear and consistent sex difference in allele size distribution was observed at the Stn19 locus throughout the 15 populations investigated. Males were distinguishable by the presence of distinct male-specific alleles, which were lacking in all females. There was no indication of recombination between sex and the Stn19 locus in the 647 individuals tested. The degree of genetic differentiation between the $X$ and $Y$ chromosomes was much higher than that of interpopulation differentiation in the respective chromosomes.

Conclusions: Our results indicate that the Stn19 locus can be used for molecular sex identification in Fennoscandian nine-spined sticklebacks. The consistent pattern of high allelic differentiation between the $X$ and $Y$ chromosomes in these populations suggests that the sex chromosomes were already highly differentiated prior to the postglacial recolonization of Fennoscandia.
\end{abstract}

\section{Background}

Unlike mammalian or avian species, fish exhibit diverse sex-determination systems [1]. Even though many fish do not possess heteromorphic sex chromosomes, genetic sex determination has been found in a wide variety of fish species [1]. This was initially demonstrated in species displaying sex-linked phenotypic traits such as skin pigmentation or coloration [2-5]. Similarly, sex-linked allozyme markers have been identified in some fish species [e.g. [6-8]]. Nevertheless, it is important to note that sex-linked phenotypic traits or allozyme markers are not necessarily encoded by sex-linked genes, since the sex linkage can be a consequence of sex-specific gene expression of autosomal genes [1]. In contrast,

\footnotetext{
* Correspondence: takahito.shikano@helsinki.fi

Ecological Genetics Research Unit, Department of Biosciences, University of Helsinki, P.O. Box 65, Fl-00014, Helsinki, Finland
}

DNA polymorphisms are not affected by altered physiological and environmental conditions, and thus are better suited for sex identification. DNA markers tightly associated with phenotypic sex have been reported in several fish species [9-13]. Such DNA markers can serve as simple and reliable diagnostic tools for sex identification of immature individuals.

Sex-linked DNA markers can also provide significant insights into demographic history and phylogenetic relationships among populations. In particular, polymorphic $Y$ chromosome markers are useful in tracing paternal lineages in wild populations $[14,15]$. In humans, Y chromosome markers have been employed for the evaluation of the origin of non-African populations and sex-biased migration $[16,17]$. Despite their advantages, the utility of $\mathrm{Y}$ chromosome polymorphisms is limited to humans and some other mammals [15]. This is partly due to the difficulty of discovering polymorphic $\mathrm{Y}$ chromosome
C Biomed Central

(c) 2011 Shikano et al; licensee BioMed Central Ltd. This is an Open Access article distributed under the terms of the Creative Commons Attribution License (http://creativecommons.org/licenses/by/2.0), which permits unrestricted use, distribution, and reproduction in any medium, provided the original work is properly cited. 
markers for organisms in which sex chromosomes are not highly differentiated [15]. As such, few studies have been conducted on phylogenetic and population genetic analyses using polymorphic $\mathrm{Y}$ chromosome markers in fish [18].

Sticklebacks (Gasterosteidae) are widely used as model organisms in evolutionary biology [19-21]. The ninespined stickleback (Pungitius pungitius) is a cold-water adapted species having a circumpolar distribution in the Northern Hemisphere and is found in a wide variety of habitats [19]. This species possesses a heteromorphic $\mathrm{XY}$ chromosome pair corresponding to three-spined stickleback linkage group 12 [22,23]. Microsatellite analyses have revealed a high degree of genetic differentiation between the $\mathrm{X}$ and $\mathrm{Y}$ chromosomes over most of their length in nine-spined sticklebacks (T. Shikano, Y. Shimada \& J. Merilä, unpublished). This implies that microsatellite markers can be used as a diagnostic tool for sex identification in this species. However, the practical utility of this approach needs to be validated as the results were obtained using only two particular populations. The necessity of such a validation is exemplified by previous studies that have demonstrated populationspecificity of molecular sex identification $[10,11,24]$.

We investigated the potential utility of a microsatellite marker located on sex chromosomes for molecular sex identification in a large number of Fennoscandian ninespined stickleback populations. These populations are highly subdivided from each other as a result of their postglacial colonizations following the last glacial maximum (ca. 12000 years ago) [25]. We therefore hypothesized that similar patterns of allelic differentiation between $\mathrm{X}$ and $\mathrm{Y}$ chromosomes would be observed across the populations if the sex chromosomes had been highly differentiated prior to postglacial recolonization. To gain insights into sex chromosome differentiation and population history, we also assessed the degree of genetic differentiation between and within the sex chromosomes across the populations using the sex-linked microsatellite marker.

\section{Materials and methods}

\section{Samples}

A total of 647 adult fish were collected with seine nets or minnow traps from 15 locations, comprising three coastal, two lake and 10 pond sites in Fennoscandia (Figure 1; Table 1). Phenotypic sex was initially determined by visual inspection (i.e. nuptial coloration of males and gravidity of females; 603 specimens) or by examining gonads (44 specimens) after the fish had been anesthetised with an overdose of MS-222 (tricane methanesulphonate). All procedures were performed under license from the Animal Experiment Board in Finland (ELLA; STH379A). Total DNA was extracted

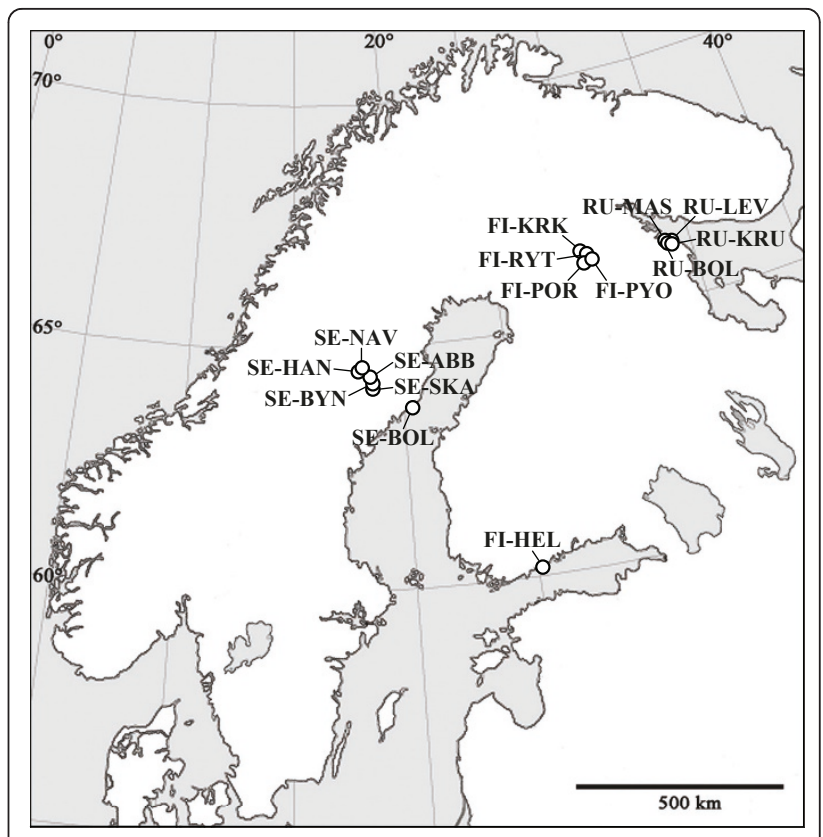

Figure 1 Sampling locations of 15 study populations of Fennoscandian nine-spined sticklebacks.

from fin clips using a silica-fine based purification method [26] following proteinase $\mathrm{K}$ digestion.

\section{Genotyping}

We surveyed genomic locations of the 11 three-spined stickleback microsatellite loci previously tested in ninespined sticklebacks [27] by subjecting these flanking sequences to BLASTN searches against the three-spined stickleback genome [28]. The microsatellite locus Stn19 [29] was mapped to three-spined stickleback linkage group 12, which corresponds to sex chromosomes in the nine-spined stickleback $[22,23]$. We genotyped this marker in 647 individuals (399 phenotypic females and 248 phenotypic males) from the 15 populations listed in Table 1. The forward primer (5'-ACAGGCATGAATGACACTGG-3') was labelled with a fluorescent dye, and the 5'-end of the reverse primer (5'-GATGAGCACAACACCTGAGC-3') was modified with a GTTT-tail [30]. Polymerase chain reactions (PCRs) were carried out using the Qiagen Multiplex PCR Kit (Qiagen) in $10 \mu \mathrm{l}$ reaction volumes containing $1 \times$ Qiagen Multiplex PCR Master Mix, 0.5× Q-Solution, 2 pmol of each primer and approx. 10-20 ng of template DNA. The reactions were performed by the following cycle: an initial activation step at $95^{\circ} \mathrm{C}$ for $15 \mathrm{~min}$, followed by $30 \mathrm{~s}$ at $94^{\circ} \mathrm{C}, 90 \mathrm{~s}$ at $53^{\circ} \mathrm{C}$ and $60 \mathrm{~s}$ at $72^{\circ} \mathrm{C}$ for 30 cycles with a final extension at $60^{\circ} \mathrm{C}$ for $5 \mathrm{~min}$. PCR products were visualized with a MegaBACE 1000 automated sequencer (Amersham Biosciences) and their sizes were determined with ET-ROX 550 size standard (Amersham 
Table 1 Sampling sites and genetic variation at the microsatellite locus Stn 19.

\begin{tabular}{|c|c|c|c|c|c|c|c|}
\hline Site code & Site & Habitat type & Coordinates & $N$ & $A$ & $H_{\mathrm{E}}$ & $F_{\mathrm{IS}}$ \\
\hline FI-KRK & Kirkasvetinenlampi & Pond & $66^{\circ} 26^{\prime} \mathrm{N}, 29^{\circ} 08^{\prime} \mathrm{E}$ & 55 & 2 & 0.391 & -0.350 \\
\hline FI-RYT & Rytilampi & Pond & $66^{\circ} 23^{\prime} \mathrm{N}, 29^{\circ} 19^{\prime} \mathrm{E}$ & 46 & 2 & 0.104 & -0.047 \\
\hline FI-PYO & Pyöreälampi & Pond & $66^{\circ} 16^{\prime} \mathrm{N}, 29^{\circ} 26^{\prime} \mathrm{E}$ & 62 & 2 & 0.324 & -0.245 \\
\hline FI-POR & Iso-Porontima & Lake & $66^{\circ} 13^{\prime} \mathrm{N}, 29^{\circ} 16^{\prime} \mathrm{E}$ & 39 & 1 & 0.000 & na \\
\hline RU-LEV & Levin Navolok & Coastal & $66^{\circ} 18^{\prime} \mathrm{N}, 33^{\circ} 24^{\prime} \mathrm{E}$ & 34 & 2 & 0.163 & -0.082 \\
\hline RU-MAS & Mashinnoje & Pond & $66^{\circ} 18^{\prime} \mathrm{N}, 33^{\circ} 24^{\prime} \mathrm{E}$ & 39 & 2 & 0.385 & -0.333 \\
\hline RU-BOL & Bolotnoje & Pond & $66^{\circ} 18^{\prime} \mathrm{N}, 33^{\circ} 24^{\prime} \mathrm{E}$ & 35 & 3 & 0.393 & -0.309 \\
\hline RU-KRU & Krugloje & Pond & $66^{\circ} 18^{\prime} \mathrm{N}, 33^{\circ} 24^{\prime} \mathrm{E}$ & 29 & 2 & 0.266 & -0.167 \\
\hline SE-NAV & Lil-Navartjärn & Pond & $64^{\circ} 34^{\prime} \mathrm{N}, 19^{\circ} 12^{\prime} \mathrm{E}$ & 63 & 2 & 0.410 & -0.393 \\
\hline SE-HAN & Hansmyrtjärn & Pond & $64^{\circ} 33^{\prime} \mathrm{N}, 19^{\circ} 10^{\prime} \mathrm{E}$ & 60 & 2 & 0.377 & -0.326 \\
\hline SE-ABB & Abborrtjärn & Pond & $64^{\circ} 29^{\prime} \mathrm{N}, 19^{\circ} 26^{\prime} \mathrm{E}$ & 38 & 3 & 0.417 & -0.326 \\
\hline SE-BYN & Bynästjärnen & Pond & $64^{\circ} 27^{\prime} \mathrm{N}, 19^{\circ} 27^{\prime} \mathrm{E}$ & 40 & 3 & 0.664 & -0.129 \\
\hline SE-SKA & Vastre-Skavträsket & Lake & $64^{\circ} 26^{\prime} \mathrm{N}, 19^{\circ} 27^{\prime} \mathrm{E}$ & 30 & 1 & 0.000 & na \\
\hline SE-BOL & Bölesviken & Coastal & $63^{\circ} 40^{\prime} \mathrm{N}, 20^{\circ} 13^{\prime} \mathrm{E}$ & 39 & 4 & 0.639 & -0.084 \\
\hline FI-HEL & Uutela & Coastal & $60^{\circ} 12^{\prime} \mathrm{N}, 25^{\circ} 11^{\prime} \mathrm{E}$ & 38 & 3 & 0.538 & 0.070 \\
\hline
\end{tabular}

$N$, number of individuals; $A$, number of observed alleles; $H_{\mathrm{E}}$, expected heterozygosity; na, not applied.

Biosciences). Alleles were scored using Fragment Profiler 1.2 (Amersham Biosciences) with visual inspection and manual corrections of alleles.

\section{Data analyses}

Expected heterozygosity and $F_{\mathrm{IS}}$ were calculated according to population and sex using FSTAT 2.9.3 [31]. The significance of $F_{\text {IS }}$ was determined by 10000 permutations. Sequential Bonferroni correction was applied to minimize type I errors [32]. To identify X and Y chromosomal alleles, genotypic frequencies and allele size distributions were compared between females and males. The degree of genetic differentiation in $\mathrm{X}$ and $\mathrm{Y}$ chromosomal alleles - both within and among populations - was evaluated using the $(\delta \mu)^{2}$ distance, which is the squared difference in the number of microsatellite repeats [33]. This analysis was performed for the $\mathrm{X}$ and $\mathrm{Y}$ chromosome alleles identified in males, using Microsatellite Analyzer 4.05 [34]. Since two populations (FIPOR and SE-SKA; see also Results) were solely comprised of females (phenotypic and genotypic), these populations were excluded from this analysis. A UPGMA dendrogram was constructed from the $(\delta \mu)^{2}$ distances using Populations 1.2 [35].

We note that the accuracy of phenotypic sexing was critical to our inference, and therefore specific care was taken to ensure that phenotypic sexes were correct. In our initial screen, 37 (5.7\%) individuals showed a mismatch between phenotypic and genotypic (see below) sex. All the mismatches corresponded to individuals that had been sexed on the basis of visual criteria; reexamination of these individuals by gonadal inspection confirmed their true sex, which matched the genotypic sex perfectly.

\section{Results}

Across the 15 populations, a total of five alleles were found at the locus Stn19 (Table 1). The number of observed alleles was three in females and four in males. In each population, one or two alleles were observed in females, whereas two to four alleles were detected in males (Table 2). No polymorphism was found in two populations (FI-POR and SE-SKA), from which only phenotypic females were available (Table 2). $F_{\text {IS }}$ values were nonsignificant for females in all populations $(P>$ 0.05 ; Table 2). In contrast, all males were heterozygous at this locus, and accordingly, most populations exhibited significant negative $F_{\text {IS }}$ values in males $(P<0.05$; Table 2).

Allele size distributions were clearly different between the sexes, and this pattern was consistent throughout the 15 populations (Figure 2). Only shorter (154, 158 and 160) alleles were identified in females, whereas both shorter and longer (174 and 176) alleles were detected in males (Figure 2). In fact, all males possessed one short and one long allele. Therefore, these longer alleles can be inferred to be located on the Y chromosome.

Assuming that the longer alleles are located on the $\mathrm{Y}$ chromosome, the number of alleles observed on this chromosome was one or two in each population (Table 2). Similarly, one or two alleles were observed in each population for the shorter alleles, which are presumed to be located on the X chromosome (Table 2). Polymorphism for $\mathrm{Y}$ chromosomal alleles was found only in one population (SE-BOL; Table 2). The number of alleles observed in each population was slightly but significantly larger in the alleles putatively located on the $\mathrm{X}$ chromosome than those on the $\mathrm{Y}$ chromosome (paired $t$-test, $\mathrm{t}_{12}=2.31, P<0.05$ ). $\mathrm{X}$ chromosomal alleles were polymorphic in four out of 
Table 2 Genetic variation at the locus Stn19 in two sexes and $X$ and $Y$ chromosomes.

\begin{tabular}{|c|c|c|c|c|c|c|c|c|c|c|}
\hline \multirow[t]{2}{*}{ Site code } & \multicolumn{4}{|c|}{ Female } & \multicolumn{4}{|c|}{ Male } & \multirow{2}{*}{$\frac{\mathrm{X}}{A}$} & \multirow{2}{*}{$\frac{\mathrm{Y}}{A}$} \\
\hline & $N$ & $A$ & $H_{\mathrm{E}}$ & $F_{\mathrm{IS}}$ & $N$ & $A$ & $H_{\mathrm{E}}$ & $F_{\mathrm{IS}}$ & & \\
\hline FI-KRK & 26 & 1 & 0.000 & na & 29 & 2 & 0.500 & $-1.000^{*}$ & 1 & 1 \\
\hline FI-RYT & 41 & 1 & 0.000 & na & 5 & 2 & 0.500 & -1.000 & 1 & 1 \\
\hline FI-PYO & 37 & 1 & 0.000 & na & 25 & 2 & 0.500 & $-1.000^{*}$ & 1 & 1 \\
\hline FI-POR & 39 & 1 & 0.000 & na & 0 & - & - & - & 1 & - \\
\hline RU-LEV & 28 & 1 & 0.000 & na & 6 & 2 & 0.500 & -1.000 & 1 & 1 \\
\hline RU-MAS & 19 & 1 & 0.000 & na & 20 & 2 & 0.500 & $-1.000^{*}$ & 1 & 1 \\
\hline$J-B$ & 18 & 2 & 0.056 & 0.000 & 17 & 2 & 0.500 & $-1.000^{*}$ & 2 & 1 \\
\hline RU-KRU & 20 & 1 & 0.000 & na & 9 & 2 & 0.500 & -1.000 & 1 & 1 \\
\hline SE-NAV & 27 & 1 & 0.000 & na & 36 & 2 & 0.500 & $-1.000^{*}$ & 1 & 1 \\
\hline SE-HAN & 30 & 1 & 0.000 & na & 30 & 2 & 0.500 & $-1.000^{*}$ & 1 & 1 \\
\hline SE-ABB & 19 & 2 & 0.102 & -0.029 & 19 & 2 & 0.500 & $-1.000^{*}$ & 2 & 1 \\
\hline SE-BYN & 19 & 2 & 0.515 & 0.080 & 21 & 3 & 0.624 & $-0.603^{*}$ & 2 & 1 \\
\hline SE-SKA & 30 & 1 & 0.000 & na & 0 & - & - & - & 1 & - \\
\hline SE-BOL & 19 & 2 & 0.494 & 0.254 & 20 & 4 & 0.609 & $-0.641^{*}$ & 2 & 2 \\
\hline Fl-HEL & 27 & 2 & 0.427 & 0.307 & 11 & 3 & 0.545 & $-0.833^{*}$ & 2 & 1 \\
\hline
\end{tabular}

$N$, number of individuals; $A$, number of observed alleles; $H_{E}$, expected heterozygosity; na, not applied. ${ }^{*} P<0.05$.

seven populations from southern and central areas $\left(60^{\circ} 12^{\prime}\right.$ $64^{\circ} 34^{\prime} \mathrm{N}$ ), but these were monomorphic in most populations from northern areas $\left(66^{\circ} 18^{\prime}-66^{\circ} 26^{\prime} \mathrm{N}\right.$; Table 2). In the coastal populations, polymorphism was detected in the Baltic Sea populations (SE-BOL and FI-HEL) whereas no

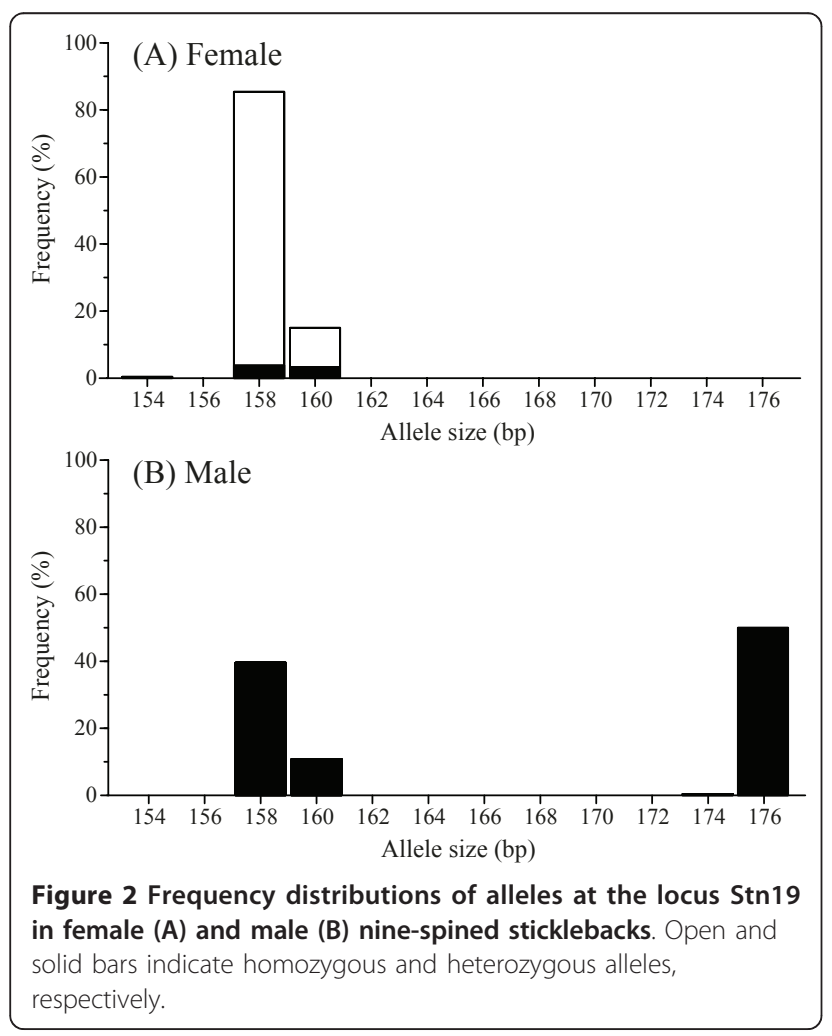

polymorphism was found in the White Sea population (RU-LEV; Table 2).

The $(\delta \mu)^{2}$ distance was much larger between the X and $Y$ chromosomal alleles than among alleles within each chromosome (Additional file 1). The UPGMA dendrogram constructed from the $(\delta \mu)^{2}$ distances showed two major clusters corresponding to the $\mathrm{X}$ and $\mathrm{Y}$ chromosomal alleles across the populations (Figure 3$)$. The $(\delta \mu)^{2}$ distance between the $\mathrm{X}$ and $\mathrm{Y}$ chromosomal alleles was 64.0 to 81.0 in each population with a mean of 71.4 $(\mathrm{SD}=6.9)$.

\section{Discussion}

Our results demonstrated a clear and consistent difference in allele size distributions at the microsatellite locus Stn19 between sexes in a number of Fennoscandian populations. Males were distinguishable by the presence of distinct sex-specific alleles (174 and 176), whereas females were characterized by the absence of these alleles. Given the male heterogamy in this species [36], these male-specific alleles should be located on the $Y$ chromosome. Since the observed pattern was consistent in a large number of individuals from various populations, allelic variation in this locus can be used as a diagnostic tool for sex identification in immature individuals, as well as in adults when phenotypic criteria are deemed to be unreliable. In our experience, phenotypic sexing by using external criteria is not possible at juvenile stages, and will sometimes lead to errors even in adult fish.

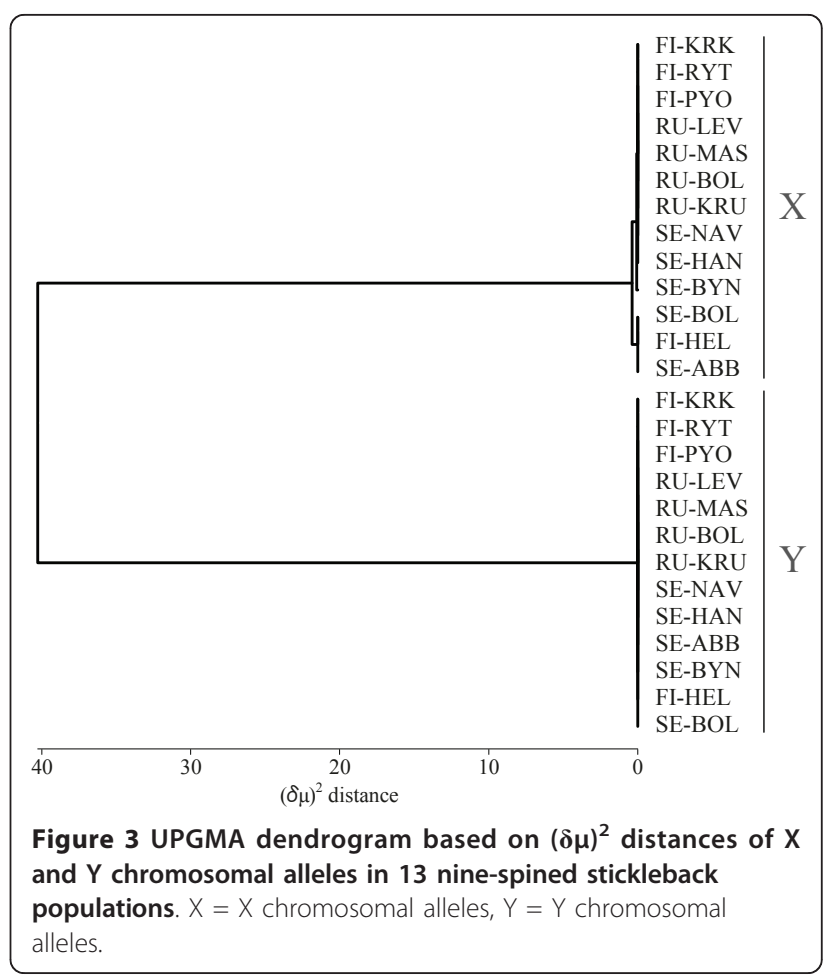


Despite our large sample size, we did not find any indication of recombination between the sex-determination locus and the Stn19 locus. Consistent patterns of sex-linked allelic differentiation were observed for other microsatellite loci located on the sex chromosomes independent of their physical location (T. Shikano, Y. Shimada \& J. Merilä, unpublished). Therefore, distinct allelic divergence at the Stn 19 locus between the sex chromosomes could be due to suppression of recombination between these chromosomes rather than due to tight physical linkage between the Stn19 locus and the sex-determination locus. Indeed, the sex chromosomes of nine-spined sticklebacks are cytogenetically distinguishable [36]. Thus, both molecular and cytogenetic characteristics indicate that sex chromosomes are highly differentiated from each other in this species. Yet, the fact that Stn19 and other sex-linked microsatellite loci (T. Shikano, Y. Shimada \& J. Merilä, unpublished) maintain homologous amplification sites between the $\mathrm{X}$ and Y chromosomes suggests a high level of DNA similarity between these chromosomes. In the case of humans, where sex chromosomes initiated differentiation 240320 million years ago [37], $\mathrm{X}$ and $\mathrm{Y}$ homologous microsatellite markers have been developed in limited homologous regions of these chromosomes [38-41].

Since northern Europe was covered by the continental ice sheet until approximately 12000 years ago, ninespined sticklebacks must have colonized Fennoscandia after the last glacial maximum. Based on an analysis of autosomal microsatellite markers, Fennoscandian populations are highly differentiated from each other perhaps due to founder effects following postglacial colonization [25]. Our study demonstrated that the level of genetic differentiation between the $\mathrm{X}$ and $\mathrm{Y}$ chromosomes was much larger than the interpopulation differentiation in the respective chromosomes. Because the patterns of allelic differentiation between the $\mathrm{X}$ and $\mathrm{Y}$ chromosomes were consistent in all populations, it is obvious that the sex chromosomes had been highly differentiated prior to the postglacial recolonization of Fennoscandia.

The usefulness of homologous microsatellite markers in $\mathrm{X}$ and $\mathrm{Y}$ chromosomes for the inferences of population history and sex-specific genetic structuring has been proposed in human studies [40,42-44]. Our results showed that the level of genetic variability in the $\mathrm{X}$ chromosome was lower in northern Fennoscandian populations as compared to those from central and southern Fennoscandia. This is consistent with a previous study that found a northward reduction in genetic variability at autosomal microsatellite loci [25]. In contrast, the level of genetic variability in the Y chromosome was consistently low in all populations. Similarly, mitochondrial DNA analyses revealed that one haplotype is widely distributed throughout the populations in the study area, suggesting that these populations share a common ancestry [25]. Hence, the low genetic variability of the paternal lineage supports the conclusion obtained from the maternal lineage. Further studies with more markers for the paternal lineage will be necessary to better evaluate this point, as well as to address sexspecific processes shaping population structure.

\section{Conclusions}

In summary, we have demonstrated that the microsatellite locus Stn19 shows sex-specific allelic differences in a large number of Fennoscandian nine-spined stickleback populations. Thus, this marker can be used for the sex identification of immature individuals, as well as adults when visual criteria are deemed to be unreliable. The consistent patterns of allelic differentiation between these chromosomes across the populations suggest that the sex chromosomes of nine-spined sticklebacks had been highly differentiated prior to the postglacial recolonization of Fennoscandia.

\section{Additional material}

Additional file 1: Matrix of $(\delta \mu)^{2}$ distances of $X$ and $Y$ chromosomal alleles within and between 13 nine-spined stickleback populations.

\section{Acknowledgements}

We thank Victor Berger, Göran Englund, Abigel Gonda, Tuomas Leinonen, Daniel Lussetti, Pirkko Siikamäki and people at the Oulanka Research Station and the White Sea Biological Station for help in obtaining samples. Thanks are also due to Jacquelin DeFaveri for comments on an earlier version of this paper. Our study was supported by the Academy of Finland and the Japan Society for the Promotion of Science.

\section{Authors' contributions}

TS conceived the study, collected the molecular data, conducted the analyses and wrote the manuscript. GH collected the fish samples and recorded the phenotypic sex data. JM contributed to conceiving and writing of the manuscript. All authors read and approved the final manuscript.

\section{Competing interests}

The authors declare that they have no competing interests.

Received: 19 December 2010 Accepted: 12 April 2011 Published: 12 April 2011

\section{References}

1. Devlin $\mathrm{RH}$, Nagahama Y: Sex determination and sex differentiation in fish: an overview of genetic, physiological, and environmental influences. Aquaculture 2002, 208:191-364.

2. Aida T: On the inheritance of colour in a fresh-water fish Aplocheilus latipes Temminck and Aclegel, with special reference to sex-linked inheritance. Genetics 1921, 6:554-573.

3. Wing $\mathrm{O}$ : One-sided masculine and sex-linked inheritance in Lebistes reticulates. J Genet 1922, 12:137-144.

4. Yamamoto T: Sex differentiation. In Fish Physiology. Edited by: Hoar W, Randall D. New York: Academic Press; 1969:117-175.

5. Fernando AA, Phang VPE: Colour pattern inheritance in three domesticated varieties of guppy, Poecilia reticulata. Genet Aquacult III 1990, 85:320.

6. Withler RE, MCPhail JD, Devlin RH: Electrophoretic polymorphism and sexual dimorphism in the freshwater and anadromous threespine 
sticklebacks (Gasterosteus aculeatus) of the Little Campbell River, British Columbia. Biochem Genet 1986, 24:701-713.

7. Allendorf FW, Gellman WA, Thorgaard GH: Sex-linkage of two enzyme loci in Oncorhynchus mykiss (rainbow trout). Heredity 1994, 72:498-507.

8. Liu Q, Goudie CA, Simco BA, Davis KB: Sex-linkage of glucose phosphate isomerase- $B$ and mapping of the sex-determining gene in channel catfish. Cytogenet Cell Genet 1996, 73:282-285.

9. Devlin RH, NCNeil BK, Groves TDD, Donaldson EM: Isolation of a Ychromosomal DNA probe capable of determining genetic sex in chinook salmon (Oncorhynchus tshawytscha). Can J Fish Aquat Sci 1991, 48:1606-1612.

10. Matsuda M, Kusama T, Oshiro T, Kurihara Y, Hamaguchi S, Sakaizumi M: Isolation of a sex chromosome-specific DNA sequence in the medaka, Oryzias latipes. Genes Genet Syst 1997, 72:263-268.

11. Iturra P, Medrano JF, Bagley M, Lam N, Vergara N, Marin JC: Identification of sex chromosome molecular markers using RAPDs and fluorescent in situ hybridization in rainbow trout. Genetica 1998, 101:209-213.

12. Griffiths R, Orr K, Adam A, Barber I: DNA sex identification in the threespined stickleback. J Fish Biol 2000, 57:1331-1334.

13. Brunelli JP, Wertzler KJ, Sundin K, Thorgaard GH: Y-specific sequences and polymorphisms in rainbow trout and Chinook salmon. Genome 2008, 51:739-748.

14. Jobling MA, Tyler-Smith C: The human $Y$ chromosome: an evolutionary marker comes of age. Nat Rev Genet 2003, 4:598-612.

15. Greminger MP, Krützen M, Schelling C, Pienkowska-Schelling A, Wandeler P: The quest for Y-chromosomal markers - methodological strategies for mammalian non-model organisms. Mol Ecol Res 2010, 10:409-420.

16. Wilder JA, Kingan SB, Mobasher Z, Pilkington MM, Hammer MF: Global patterns of human mitochondrial DNA and Y-chromosome structure are not influenced by higher migration rates of females versus males. Nat Genet 2004, 36:1122-1125.

17. Underhill PA, Kivisild T: Use of $\mathrm{Y}$ chromosome and mitochondrial DNA population structure in tracing human migrations. Ann Rev Genet 2007, 41:539-564.

18. Brunelli JP, Steele CA, Thorgaard GH: Deep divergence and apparent sexbiased dispersal revealed by a Y-linked marker in rainbow trout. Mol Phylogenet Evol 2010, 56:983-990.

19. Wootton RJ: The Biology of the Sticklebacks New York: Academic Press; 1976.

20. Bell MA, Foster SA: Introduction to the evolutionary biology of the threespine stickleback. In The Evolutionary Biology of the Threespine Stickleback. Edited by: Bell MA, Foster SA. Oxford: Oxford University Press; 1994:1-27.

21. Östlund-Nilsson S, Mayer I: The Biology of Other Sticklebacks. In Biology of the Three-Spined Stickleback. Edited by: Östlund-Nilsson S, Mayer I, Huntingford FA. Boca Raton, FL: CRC Press; 2007:353-372.

22. Ross JA, Urton JR, Boland J, Shapiro MD, Peichel CL: Turnover of sex chromosomes in the stickleback fishes (Gasterosteidae). PLoS Genet 2009, 5:e1000391.

23. Shapiro MD, Summers BR, Balabhadra S, Aldenhoven JT, Miller AL, Cunningham C, Bell MA, Kingsley DM: The genetic architecture of skeletal convergence and sex determination in ninespine sticklebacks. Curr Biol 2009, 19:1140-1145.

24. Nanda I, Feichtinger W, Schmid M, Schröder JH, Zischler H, Epplen JT: Simple repetitive sequences are associated with differentiation of the sex chromosomes in the guppy fish. J Mol Evol 1990, 30:456-462.

25. Shikano T, Shimada Y, Herczeg G, Merilä J: History vs. habitat type: explaining the genetic structure of European nine-spined stickleback (Pungitius pungitius) populations. Mol Ecol 2010, 19:1147-1161.

26. Elphinstone MS, Hinten GN, Anderson MJ, Nock CJ: An inexpensive and high-throughput procedure to extract and purify total genomic DNA for population studies. Mol Ecol Notes 2003, 3:317-320.

27. Mäkinen HS, Välimäki K, Merilä J: Cross-species amplification of microsatellite loci for nine-spined stickleback Pungitius pungitius. Ann Zool Fennici 2007, 44:218-224

28. Ensembl. [http://www.ensembl.org/Gasterosteus_aculeatus/Info/Index].

29. Peichel CL, Nereng KS, Ohgi KA, Cole BL, Colosimo PF, Buerkle CA, Schluter D, Kingsley DM: The genetic architecture of divergence between threespine stickleback species. Nature 2001, 414:901-905.

30. Brownstein MJ, Carpten JD, Smith JR: Modulation of non-templated nucleotide addition by Taq DNA polymerase: primer modifications that facilitate genotyping. BioTechniques 1996, 20:1004-1010.
31. Goudet J: FSTAT (Version 1.2): a computer program to calculate Fstatistics. J Hered 1995, 86:485-486.

32. Rice WR: Analyzing tables of statistical tests. Evolution 1989, 43:223-225.

33. Goldstein DB, Ruíz-Linares A, Feldman M, Cavalli-Sforza LL: Genetic absolute dating based on microsatellites and the origin of modern humans. Proc Natl Acad Sci USA 1995, 92:6720-6727.

34. Dieringer D, Schlötterer C: Microsatellite analyser (MSA): a platform independent analysis tool for large microsatellite data sets. Mol Ecol Notes 2003, 3:167-169.

35. Langella O: Populations 1.2.28. Logiciel de génétique des populations. Gif-sur-Yvette: CNRS UPR9034 2002

36. Ocalewicz K, Fopp-Bayat D, Woznicki P, Jankun M: Heteromorphic sex chromosomes in the ninespine stickleback Pungitius pungitius. J Fish Biol 2008, 73:456-462.

37. Lahn BT, Page DC: Four evolutionary strata on the human $X$ chromosome. Science 1999, 286:964-967.

38. Malaspina P, Ciminelli BM, Viggiano L, Jodice C, Cruciani F, Santolamazza P, Sellitto D, Scozzari R, Terrenato L, Rocchi M, Novelletto A: Characterization of a small family (CAIII) of microsatellite-containing sequences with X-Y homology. J Mol Evol 1997, 44:652-659.

39. Kotliarova ES, Toda T, Takenaka O, Matsushita I, Hida A, Shinka T, Goto J, Tokunaga $K$, Nakagome $Y$, Nakahori Y: Novel $(C A)_{n}$ marker DXYS241 on the nonrecombinant part of the human $Y$ chromosome. Hum Biol 1999, 71:261-275.

40. Carvalho-Silva DR, Pena SD: Molecular characterization and population study of an X chromosome homolog of the Y-linked microsatellite DYS391. Gene 2000, 247:233-240.

41. Balaresque P, Toupance B, Heyer E, Crouau-Roy B: Evolutionary dynamics of duplicated microsatellites shared by sex chromosomes. J Mol Evol 2003, 57:S128-S137.

42. Scozzari R, Cruciani F, Malaspina P, Santolamazza P, Ciminelli BM, Torroni A, Modiano D, Wallace DC, Kidd KK, Olckers A, Moral P, Terrenato L, Akar N, Qamar R, Mansoor A, Mehdi SQ, Meloni G, Vona G, Cole DE, Cai W, Novelletto A: Differential structuring of human populations for homologous X and Y microsatellite loci. Am J Hum Genet 1997, 61:719-733.

43. Karafet T, de Knijff P, Wood E, Ragland J, Clark A, Hammer MF: Different patterns of variation at the $\mathrm{X}$ - and $\mathrm{Y}$-chromosome-linked microsatellite loci DXYS156X and DXYS156Y in human populations. Hum Biol 1998, 70:979-992.

44. Balaresque P, Manni F, Dugoujon JM, Crouau-Roy B, Heyer E: Estimating sex-specific processes in human populations: Are XY-homologous markers an effective tool? Heredity 2006, 96:214-221.

doi:10.1186/1756-0500-4-119

Cite this article as: Shikano et al:: Molecular sexing and population genetic inference using a sex-linked microsatellite marker in the ninespined stickleback (Pungitius pungitius). BMC Research Notes 2011 4:119.

\section{Submit your next manuscript to BioMed Central and take full advantage of:}

- Convenient online submission

- Thorough peer review

- No space constraints or color figure charges

- Immediate publication on acceptance

- Inclusion in PubMed, CAS, Scopus and Google Scholar

- Research which is freely available for redistribution

Submit your manuscript at www.biomedcentral.com/submit
C Biomed Central 